\title{
CHEMICAL AND BIOLOGICAL STUDY OF EUGENIA STIPITATA MC VAUGH COLLECTED IN THE COLOMBIAN ANDEAN REGION
}

\author{
ANDREE ÁLVAREZ*, ÁNGEL JIMÉNEZ, JONH MÉNDEZ, ELIZABETH MURILLO \\ Department Chemistry, Natural Products Research Group (GIPRONUT), Science School, University of Tolima - 730 006, Ibagué, Colombia. \\ Email: andreepassport@hotmail.com
}

Received: 11 May 2018, Revised and Accepted: 09 August 2018

\section{ABSTRACT}

Objective: The main objective of this study is to evaluate the chemical and bioactive properties of Eugenia stipitata (Myrtaceae) fruit seeds collected in the Andean region of Colombia using an ethanolic extract, a dichloromethane fraction (DF), and a hydroalcoholic residue.

Methods: E. stipitata seeds were evaluated using bromatological analysis; these were macerated (ethanol 96\%) and partitioned (dichloromethane). Phytophenols composition of the samples was tested by high-pressure liquid chromatography-mass spectrometry and Folin-Ciocalteu method, then calculated as gallic acid equivalents (GAEs). Antiradical capacity was tested by 2,2-diphenyl-1-picrylhydrazyl (DPPH•) and 3-ethylbenzthiazoline-6sulfonic acid $\left(\mathrm{ABTS}^{\circ}\right)$ and inhibitory concentration $50 \%\left(\mathrm{IC}_{50}\right.$ ) was calculated; antioxidant capacity was determined using ferric reducing antioxidant power, oxygen radical absorbance capacity, and $\mathrm{OH}^{\bullet}$ radical and hemolysis inhibition assays. Anthelmintic activity against Panagrellus redivivus and ovine gastrointestinal (GI) nematodes and toxicity on human blood cells were tested.

Results: E. stipitata seeds contain protein, sulfur, boron, iron, and copper. The ethanolic extract exhibited significant anthelmintic activity against freeliving and GI nematodes, which would be associated with the phytophenols content, mostly tannins (29.14 g GAE/100 g). DF displayed the highest antiradical capacity in $\mathrm{DPPH}^{\bullet}$ and $\mathrm{ABTS}^{\bullet+}\left(\mathrm{IC}_{50} 2.65\right.$ and $0.33 \mathrm{mg} / \mathrm{l}$, respectively) methods, antioxidant capacity, and hemolysis inhibition of human erythrocytes $\left(\mathrm{IC}_{50:} 200 \mathrm{mg} / \mathrm{l}\right)$. There were no toxic metabolites to human blood cells.

Conclusion: These findings would be useful for promoting the use of E. stipitata seeds, collected in the Colombian Andean region, in biotechnological processes. This is the earliest paper showing a study carried out in Colombia with an interest in evaluating chemical and biological characteristics of E. stipitata seeds.

Keywords: Antioxidant, Anthelmintic activity, Phenolic compounds, Gastrointestinal nematodes, Arazá, Myrtaceae.

(c) 2018 The Authors. Published by Innovare Academic Sciences Pvt Ltd. This is an open access article under the CC BY license (http://creativecommons. org/licenses/by/4. 0/) DOI: http://dx.doi.org/10.22159/ajpcr.2018.v11i12.27253

\section{INTRODUCTION}

The exotic fruit of arazá, Eugenia stipitata (Myrtaceae), is originally from Western Amazon, in the region bordered by Marañón and Ucayali rivers, and the proximities of the Requena Province and Amazon river source [1,2]. Mc Vaugh [3] verified the existence of two different populations of E. stipitata, but with common qualitative features which forced to consider them as subspecies: Stipitata and sororia; this latter is grown in Colombia, Peru, Brazil, Ecuador, Bolivia, and Costa Rica $[1,3]$.

The attractive organoleptic features of the E. stipitata fruit, along with the knowledge of its nutritional properties and production systems, have made the Amazon Institute of Scientific Investigation of Colombia turn it into one of the species prioritized in its strategic line of Development of Productive Alternatives and Green Markets [4]. However, its cultivation and development are not exclusive from the Amazon; there are also monocrops in the departments of Meta, Guaviare, Caquetá, and Putumayo; with lesser frequency, it is located in some departments of the Andean region such as Cundinamarca, Valle del Cauca, Caldas, Antioquia, and Tolima [5,6].

The arazá fruit shows chemical characteristics, intense aroma, and a sweet-sour taste being very appreciated in agroindustrial processings, which has motivated the performance of multiple studies with the purpose of knowing its harvest physiology, ripening process, and post-harvest technologies [6,7]. Nutritional interest studies are also remarkable [4] as well as technological viability of frozen pulp [8], fruit commercialization perspectives [9-11], industrial potentiality [7,12], antioxidant capacity [1,13,14], antimutagenic agent [15], and antidiabetic [16]; this latter, related to the high content of compound derivatives from quercetin, which are molecules capable of inhibiting the activity of $\alpha$-glucosidase, an enzyme involved in carbohydrates metabolism.

The attributes mentioned above, as well as the high yield in the pulp of the ripe fruit, would make E. stipitata subsp. sororia an important source of basic material for Colombian agroindustry. However, some difficulties in fruit post-harvest handling and the lack of quality technical normativity, among others, have created obstacles in progress of production line of arazá, in comparison with other fruits related to it, such as guava (Psidium guajava) $[1,10,17]$. Even though most researches have been oriented to the knowledge of the pulp and/or peel $[13,14,17-19]$, leaving aside the biotechnological and/or pharmacological potentialities of the seed, which takes $30 \%$ of the fruit volume, it is $22 \%$ of fresh weight and $84 \%$ of dry matter. The interest of farmers, agricultural technicians, and professionals in regions where there are arazá plantations has made that, until now, studies related to the seeds are fundamentally of agronomic type, although they are mentioned as an important part for the plant growth.

Taking into account the information given above, this study was focused on evaluating the chemical and bioactive properties of the fruit seeds and the organic fractions derived from them. All the data obtained will provide an enhanced knowledge of the promising nutritional/ pharmacological value of this product as a social and economic alternative for rural populations in Colombia. 


\section{MATERIALS AND METHODS}

\section{Chemical reagents and biological material}

All chemicals used in analysis as 2,2-diphenyl-1-picrylhydrazyl (DPPH), 3-ethylbenzthiazoline-6-sulfonic acid (ABTS), digitonin, hydrogen peroxide, and 3-(4,5-dimethyltiazol-2-il)-2,5-tetrazolium diphenyl bromide were purchased from SIGMA-ALDRICH ${ }^{\circledR}$ (St. Louis, MO, USA). The chromatographic solvents were acetonitrile liquid chromatographymass spectrometry (LC-MS) grade from J.T. Baker (Deventer, The Netherlands) and water purified in a Milli-Q system from Millipore (Bedford, MA, USA). The other chromatographic chemicals used were high-pressure LC grade supplied also from J.T. Baker. Other chemicals employed were analytical grade (Merck, USA). Free life Panagrellus redivivus nematode strain was provided by the Tibaitatá research center from Corpoica, Colombia. Gastrointestinal (GI) nematodes were collected from stool taken directly from the rectal ampoule of ruminants at the Northern Regional University Center, University of Tolima, Armero, Tolima ( $5^{\circ} 00^{\prime} 08.10^{\prime \prime} \mathrm{N}, 74^{\circ} 54^{\prime} 31.33^{\prime \prime}$ ) $)$. The permission to use living organisms and/or human samples was authorized by the Ethics Committee of the University of Tolima.

\section{Collecting area}

Arazá fruits (E. stipitata Mc Vaugh) were collected in the rural area of the municipality of San Sebastián de Mariquita $\left(05^{\circ} 12^{\prime} 04^{\prime \prime}\right.$ N, $74^{\circ} 53^{\prime}$ $46^{\prime \prime} 0$ ). The region is a bioclimatic transition zone between humid to very humid weather, with an annual precipitation level of $2194 \mathrm{~mm}$, equatorial climate and temperatures between $23^{\circ} \mathrm{C}$ and $28^{\circ} \mathrm{C}$. The land corresponds to the geostructure of the Andean Central Mountain Range and includes the morphostructural sets of the Eastern flank or the Eastern Mountain Range, showing an elevation of 350-1400 m.a.s.l. [20]. Mariquita is, nowadays, a developing center being remarkable in the fruit sector of the Tolima Department (Colombian Andean Central Area).

\section{Collection and preparation of plant material}

Fruit material, in optimal phytosanitary condition, was collected in February 2016 in small monocrops surrounding Mariquita Municipality. A complete specimen (leaves, flowers, and fruit) was prepared and determined in the National Herbarium of Colombia; a voucher is deposited there. A fraction of the seed, manually separated from the fruit, was submitted to a drying process $\left(45 \pm 20^{\circ} \mathrm{C}, 24 \mathrm{~h}\right)$. Then, it was crushed, degreased with $\mathrm{n}$-hexane by Soxhlet extraction method and macerated with ethanol (96\%), renewing the solvent after $2 \mathrm{~h}$ until depletion of the sample. Raw ethanolic extract (REE) was fractioned liquid-liquid with dichloromethane, obtaining a fraction (DF) and a hydroalcoholic residue (HR). The solvent was vacuum-evaporated $\left(45^{\circ} \mathrm{C}\right.$, Rotavapor R-114, Büchi, Flawil, Sweden) and REE, DF, and HR were stored $\left(-85^{\circ} \mathrm{C}\right.$, Freezer Kaltis 390$)$ until further analysis.

\section{Mineral and bromatological analysis}

The moisture content, ash, crude fat, crude protein, and crude fiber were determined on a portion of the dry seed. Similarly, major (K, Na, Mg, and $\mathrm{Ca}$ ) and minor $(\mathrm{Fe}, \mathrm{Mn}, \mathrm{Cu}$, and $\mathrm{Zn}$ ) minerals were determined by the atomic absorption spectrophotometric method (ThermoScientific iCE 3000 Series AA), while P, B, and S were quantified by UV-vis spectrophotometry (Evolution $260 \mathrm{BIO}$ ). All the determinations were performed under the AOAC standard indications [21]. Total sugar was estimated according to the method described by Nelson [22].

\section{Physicochemical characterization of extract and fractions}

REE, DF, and HR were standardized by some physicochemical determinations (color, $\mathrm{pH}$, density, and Brix) and a preliminary phytochemical analysis, attending Harborne's indications [23]. Besides, in every plant product was measured total phenols and non-tannic phenols content by applying Folin-Ciocalteu method with some modifications reported by Fidrianny et al. [24], the tannins content was established as the difference between them [25]. The results were expressed in grams of gallic acid equivalent per every hundred grams of sample (g GAE/100 g).

For REE, the chemical profile was carried out using a high-performance liquid chromatographic analysis on a Waters Alliance 2695 separation module system, coupled to a double canal $\lambda$ absorbance (280 and $320 \mathrm{~nm}$ ) detector. Compounds were separated with a Waters Atlantis dC18 column ( $5 \mu \mathrm{m} ; 2.1 \mathrm{~mm} ; 150 \mathrm{~mm})$, using a gradient system with a mobile phase which consisted in $\mathrm{H}_{2} \mathrm{O}$ (solvent $\mathrm{A}, 0.1 \% \mathrm{v} / \mathrm{v}$ formic acid) and methanol 100\% (solvent $\mathrm{B}, 0.1 \% \mathrm{v} / \mathrm{v}$ acetic acid). The flow rate was $0.500 \mathrm{ml} / \mathrm{min}$. A linear gradient elution was performed by varying the proportion of solvent A to solvent B, according to Delpino-Rius et al. [26]. The data were acquired using the chromatographic behavior and UV-vis absorption spectra, together with published data on the main phenolic compounds in the samples. To quantify, calibration curves were built tracing chromatographic peak areas measured in the specific wavelengths of the chemical standards (catechin, epicatechin, procyanidin B1, procyanidin B2, eriodictyol7-0-rutinoside, quercetin-3-0-galactoside, quercetin-3-0-glucoside, quercetin-3-0-rhamnoside, quercetin-3-0-rutinoside, kaempferol-3O-rutinoside, isorhamnetin-3-0-rutinoside, arbutin, gallic acid, caffeic acid, p-coumaric acid, ferulic acid, sinapic acid, gallic acid, isoquercitrin, phloridzin, chlorogenic acid, quercitrin, rutin).

\section{Antioxidant and antiradical capacity}

Antiradical capacity (the ability of compounds of the tested samples to react with free radicals) was evaluated using $\mathrm{DPPH}^{*}$ [27] and $\mathrm{ABTS}^{*+}[28]$ methods. In terms of the radical-scavenging ability of REE, $\mathrm{DF}$, and HR compounds, the inhibitory concentration $50 \%\left(\mathrm{IC}_{50}\right)$ value (sample concentration that stabilizes in a $50 \% \mathrm{DPPH}^{*}$ or $\mathrm{ABTS}^{*+}$ radical), the antioxidant potential ( $\mathrm{AP}=1 / \mathrm{IC}_{50}$, expressed in percentage), and Trolox-equivalent antioxidant capacity (TEAC) were established [29]. At that time, the antioxidant capacity (ability to inhibit the process of oxidation) was determined using four in vitro test systems, that is, the oxygen radical absorbance capacity (ORAC), the ferric reducing ability of plasma (FRAP), and $\bullet \mathrm{OH}$ radical inhibition [30-32], complemented with anti-hemolysis effect on erythrocyte suspension from healthy volunteers [33]. All spectrophotometric measurements were performed with a 96-hole microplate reader UV-vis (Multiskan ${ }^{\circledR}$ GO Thermo scientific).

\section{In vitro anthelmintic assays}

The anthelmintic efficacy of REE, DF, and HR against free-living (FL) nematodes ( $P$. redivivus) and GI nematodes was determined. For the culture and maintenance of $P$. redivivus, the methodology reported by Pica was followed [34]. The GI nematode genres collected were determined according to their main morphological features with foundation on the information stated by Van Wyk and Mayhew [35].

\section{Toxicity over $P$, redivivus}

Toxicity over $P$. redivivus was estimated by separating the adult organisms from the larvae with a sieve $(150 \mu \mathrm{m})$. The sample was added $(400 \mu \mathrm{l})$ to a suspension with 50 larvae (leaving a final volume of $900 \mu \mathrm{l}$ with isotonic buffer). The sample was replaced with buffer (negative control) and ethanol at 96\% (positive control). Treatments were incubated $\left(26^{\circ} \mathrm{C}, 24 \mathrm{~h}\right)$ and the mortality percentage (M\%) was established using the following formula:

$$
\mathrm{M} \%=\frac{\mathrm{DL}}{50}
$$

where DL is the number of dead larvae. With this data, $\mathrm{LC}_{50}$ lethal concentration for $50 \%$ of larvae was determined [34].

\section{Collection of GI nematodes eggs}

Eggs were collected from the feces analyzed using the conventional method of McMaster reported by Paolini et al. [36]. Fecal matter of sheep infected with strains of GI parasites was freshly collected and weighed. First of all, $1 \mathrm{~g}$ of feces was analyzed to calculate the number of eggs in the sample (N1). The initial amount of eggs (N) contained in the fecal mass was then determined as the product of $\mathrm{N} 1$ by the total weight (P). After N1 and N were determined, the fecal mass was stirred continuously for dissolution in five times its volume. The mixture was then poured through a series of sieves decreasing mesh $(200 \mu \mathrm{m}$, 
$125 \mu \mathrm{m}$, and $40 \mu \mathrm{m})$. The residue on the final sieve was collected in a small volume of water and centrifuged. The pellet was added to a saturated sodium chloride $(\mathrm{NaCl})$ solution and then centrifuged again. The supernatant was then filtered and the residue was washed three times followed by centrifugation. The resultant pellet was added to a known volume of sterile distilled water.

\section{GI nematodes egg hatch assay}

Approximately, 100 eggs suspension and $10 \mu \mathrm{l}$ of the sample were leaving to a final volume of $2 \mathrm{ml}$ with sterile distilled water. Treatments were incubated $\left(30^{\circ} \mathrm{C}, 24 \mathrm{~h}\right)$ and non-hatched eggs number was determined. Benzimidazole solution $(400 \mu \mathrm{g} / \mathrm{ml})$ was used as a positive control and distilled water as negative control. With the obtained information, $\mathrm{IC}_{50}$ (concentration of sample for $50 \%$ egg hatching inhibition) was calculated.

\section{GI nematodes cuticle loss inhibition assay}

The cuticle loss inhibition was evaluated on organisms in the $L_{3}$ stage [37]. A suspension of approximately $1200 \mathrm{~L}_{3}$ was applied to the sample $(30 \mu \mathrm{l})$ and the volume was brought to $10 \mathrm{ml}$ with sterile distilled water. Albendazole solution $(400 \mu \mathrm{g} / \mathrm{ml})$ was used as a positive control and sterile distilled water as negative control. Treatments were incubated $\left(22^{\circ} \mathrm{C}, 3 \mathrm{~h}\right)$ and centrifuged $(4200 \mathrm{rfc}, 2 \mathrm{~min})$; the washing was repeated 3 times with sterile distilled water, discarding $8 \mathrm{ml}$ of the supernatant every time. Each solution treatment $\left(100 \mathrm{~L}_{3}, 100 \mu \mathrm{l}\right.$ of the sample, and $250 \mu \mathrm{l}$ final volume) per well was exposed to sodium hypochlorite ( $\mathrm{NaClO}, 1.5 \mathrm{ml}$ at $0.187 \%, 10 \mathrm{~min}$ ) action, a drop of lugol was added and the number of organisms with and free cuticle was counted. Cuticle loss inhibition percentage (CLI\%) was calculated using the following equation:

$\mathrm{CLI} \%=\frac{\mathrm{WC} \times 100}{\mathrm{WC}+\mathrm{FC}}$

where WC and FC is the number of organisms with cuticle and free cuticle, respectively. With the obtained values, $\mathrm{IC}_{50}\left(50 \% \mathrm{~L}_{3}\right.$ cuticle loss inhibitory concentration) was calculated.

\section{GI nematodes motility and mortality inhibition assay}

To verify the effect of the samples phytoconstituents on GI nematodes, motility inhibition and mortality assays were conducted. To eliminate the larval cuticle, $2 \mathrm{ml}$ of $\mathrm{L}_{3}$ suspension was exposed at $\mathrm{NaClO}(0.187 \%, 5 \mathrm{~min})$, the treatments were centrifuged $\left(470 \mathrm{rfc}, 4^{\circ} \mathrm{C}, 5 \mathrm{~min}\right.$ ) discarding $1.8 \mathrm{ml}$ of supernatant; the washing was repeated 3 times with sterile distilled water. The $100 \mu \mathrm{l}$ of $\mathrm{L}_{3}$ larvae solution were placed in a microplate and equal volume sample was added ( $250 \mu \mathrm{l}$ final volume per well). Ivermectin was used as a positive control and sterile distilled water as negative control. The treatments were incubated $\left(26^{\circ} \mathrm{C}, 24 \mathrm{~h}\right)$ and anthelminthic action was determined [38]. The alive (rolled) and dead (immotile) $\mathrm{L}_{3}$ stage larvae were counted in each well. Larval motility inhibition percentage (LMI\%) was calculated using the following formula:

$$
\mathrm{LMI} \%=\frac{\mathrm{RL} \times 100}{\mathrm{TL}}
$$

where RL is the number of alive rolled larvae in test samples and TL is the total of larvae. With the obtained values, $\mathrm{IC}_{50}$ (motility inhibitory concentration for $50 \%$ of $\mathrm{L}_{3}$ ) was calculated. Mortality percentage (M\%) was calculated using the following equation:

$$
\mathrm{M} \%=\frac{\mathrm{DL} \times 100}{\mathrm{TL}}
$$

where DL is the number of dead larvae and TL the total of larvae. Using the previous data, $\left(\mathrm{LC}_{50}\right.$ of $\left.\mathrm{L}_{3}\right)$ was determined.

\section{Cytotoxicity on human peripheral blood mononuclear cells}

The human blood samples were obtained from healthy volunteers. For leukocyte isolation, the protocol proposed by the Viral and Human
Genomics Lab from the Medicine of School from San Luis Potosi Autonomous University [39] was used. Cytotoxic potentials of REE was performed according to the colorimetric model with MTT [40]. The sample $(25 \mu \mathrm{l}, 4000 \mathrm{mg} / \mathrm{l})$, the suspension of leukocytes $(25 \mu \mathrm{l})$, and MTT tetrazolium salt $(50 \mu \mathrm{l}, 0.04 \mathrm{mg} / \mathrm{l}$, dissolved in PBS $\mathrm{pH}$ 7.4) were added to each well of Microplate reader (Multiskan ${ }^{\circledR}$ GO Thermo scientific), and mixed thoroughly (1 $\mathrm{min})$. After plate incubation $\left(37^{\circ} \mathrm{C}, 2 \mathrm{~h}\right)$, dimethylsulfoxide (DMSO, $\left.100 \mu \mathrm{l}\right)$ was added to each well and mixed thoroughly in order to dissolve the formed blue crystals of formazan. Dilution solvent was used as sample blank, a digitonin solution (1\%) as negative control and cells without extract treatment as a positive control. All plates were then shaken for $10 \mathrm{~min}$ and incubated for $2 \mathrm{~h}$. The optical density of wells was measured by microplate reader at wavelength $570 \mathrm{~nm}$ [41]. Cell viability (CV\%) was calculated as \% of the metabolic activity of sample compounds using the following formula:

$\mathrm{CV} \%=\frac{(\mathrm{AbsT}-\mathrm{AbsB}) \times 100}{\mathrm{AbsC}-\mathrm{AbsB}}$

where AbsT is treatment absorbance; $\mathrm{AbsB}$, sample blank absorbance; AbsC, positive control absorbance.

\section{Toxicity on human erythrocytes}

The toxicity of plant samples was tested under in vitro conditions on human blood cells [33]. An erythrocyte solution $(400 \mu \mathrm{l}$ at $5 \%$ in PBS, pH 7.4) was added to REE, DF, or HR solution ( $40 \mu \mathrm{l}, 1500-7500 \mathrm{mg} / \mathrm{l})$. Dilution solvent ( $40 \mu \mathrm{l}$ ) was used as sample blank; negative control was carried out inoculating erythrocytes with PBS $(40 \mu \mathrm{l})$, whereas digitonin solution $(1 \% \mathrm{w} / \mathrm{v})$ for cytotoxicity positive control was used. Every treatment was adjusted to $1 \mathrm{ml}$ final volume with PBS, incubated $\left(37^{\circ} \mathrm{C}\right.$, $20 \mathrm{~min}$ ), and centrifuged ( $500 \mathrm{rcf}, 5 \mathrm{~min}$ ). Thereafter, the absorbance of the supernatant $(200 \mu \mathrm{l})$ was read at $540 \mathrm{~nm}$. Hemolysis percent (H\%) was calculated using the following equation:

$\mathrm{H} \%=\frac{\text { AbsC }-(\text { AbsT }- \text { AbsB })}{\text { AbsC }} \times 100$

where $\mathrm{AbsC}$ is the positive control absorbance; $\mathrm{AbsB}$ is sample blank absorbance; AbsT is treatment absorbance.

\section{Statistical analysis}

The reported values represent the analysis of at least three separate replicates for each sample \pm standard deviation. Statistical analysis of the data was done using one-way variance analysis (ANOVA). Values of $p<0.05$ were considered statistically significant, to which variance normality and homogeneity assumptions were verified $(p>0.01)$. The $\mathrm{IC}_{50}$ values were calculated using linear regression analysis. All the processing was performed with the STATGRAPHICS Centurion XV.II. Package.

\section{RESULTS AND DISCUSSION}

E. stipitata Mc Vaugh fruit is characterized by being a globose berry (30-800 g) with mild pubescence on the epicarp and because the edible part (bittersweet flavor) holds an approximate number of 20 monoembrionic seeds $(0.3-1.5 \mathrm{~cm}$, diameter; $0.3-2.5 \mathrm{~cm}$, length; $0.1-$ $4.3 \mathrm{~g}$, weight; they are $84 \%$ of dry matter), distributed in typical form along the internal cavity of the fruit (axial placentation). According to Akamine and Goo [42], fruits of Eugenia genus are not climacteric. However, Galvis and Hernández [43] argue the contrary, even though the total production of ethylene in arazá still is unknown [1].

\section{Mineral and bromatological analysis}

The results of the nutritional composition of arazá whole seed, in relation to their edible part, are presented in Table 1. A critical look at Table 1 shows that E. stipitata seeds recorded a higher value of nutrient contents than the edible part. Therefore, nutrient profile of 
Table 1: Nutritional content of arazá fruit seed and edible part

\begin{tabular}{lll}
\hline Parameters & \multicolumn{2}{l}{ Nutrient content percentage } \\
\cline { 2 - 3 } & Seed & Edible part* \\
\hline Moisture & $38.80 \pm 1.40$ & $96.00 \pm 0.10$ \\
Dry matter & $71.20 \pm 1.80$ & $4.00 \pm 0.10$ \\
Ashes & $1.35 \pm 0.05$ & $1.16 \pm 0.00$ \\
Crude fat & $2.05 \pm 0.01$ & $0.004 \pm 0.10$ \\
Crude protein & $3.06 \pm 0.07$ & $0.47 \pm 0.02$ \\
Crude fiber & $5.98 \pm 0.04$ & $1.56 \pm 0.17$ \\
Total carbohydrates & $31.12 \pm 1.49$ & $1.96 \pm 0.35$ \\
Mineral analysis & & \\
Majora elements $(\%)$ & & \\
$\quad$ Calcium & $0.15 \pm 0.00$ & $0.005 \pm 0.000$ \\
$\quad$ Magnesium & $0.05 \pm 0.00$ & $0.002 \pm 0.000$ \\
$\quad$ Sodium & $0.12 \pm 0.00$ & $0.001 \pm 0.000$ \\
$\quad$ Potassium & $0.50 \pm 0.00$ & $0.020 \pm 0.004$ \\
$\quad$ Phosphorus & $0.07 \pm 0.00$ & $0.007 \pm 0.000$ \\
Minor elements (mg/kg) & & \\
$\quad$ Zinc & $4.90 \pm 0.31$ & $1.80 \pm 0.70$ \\
$\quad$ Boron & $41.80 \pm 0.80$ & $\mathrm{NR}$ \\
Sulfur & $100 \pm 5.00$ & $\mathrm{NR}$ \\
Copper & $16.20 \pm 0.60$ & $\mathrm{NR}$ \\
Iron & $20.90 \pm 1.10$ & $1.50 \pm 0.20$ \\
Manganese & $1.40 \pm 0.40$ & $\mathrm{NR}$ \\
\hline Takn & & \\
\hline
\end{tabular}

*Taken from Barrantes, Yaya, and Arias[45] and Rogez et al. [17],

NR: Non-reported

arazá seed shall be established as: Carbohydrates (31.12\%)>crude fiber $(5.98 \%)>$ sulfur $(100 \mathrm{mg} / \mathrm{kg})>$ boron $(41.8 \mathrm{mg} / \mathrm{kg})>$ iron $(20.9 \mathrm{mg} / \mathrm{kg})$ and copper $(16.2 \mathrm{mg} / \mathrm{kg})$. Such nutritional attributes, added to the succulence, aroma, flavor, texture, and color of the edible portion, make of arazá an appetizing fruit option. The basic chemical composition of the tested seeds was higher to that previously reported by P. guajava fruit, a Myrtaceae of high commercial importance [44].

On the other hand, the moisture content for arazá seed (38.80\%) was lower when compared with the edible part (96\%). Coriaceous and thin tegument which covers the seed would explain in part the low humidity content of them. Consequently, it must be understood that over $50 \%$ are nutrients stored as dry matter in the seed. Moisture content is among the most vital and mostly used measurement in the processing, preservation, and storage of food [46].

It is also of notice the considerable difference in carbohydrate content between the seed and the edible part (16:1), this has a foundation if it is considered that carbohydrates are part of the material that satisfies cell energetic demands for the seedling support. Many primary metabolites act as precursors or are pharmacologically active metabolites in bioactive extracts. Carbohydrates are the main energy reserves in foods of plant origin; they are precursors of certain lipids, proteins, ascorbic acid, and inositol [46], among other functions. In the case of arazá seed, a significant part of these metabolites would be constituted by tegument covering the seed, which possibly helps seed dispersion and fixation on the substrate. Crude fiber in food or plant is an indication of the level of non-digestible carbohydrate and lignin. The value obtained $(5.98 \%)$ for seeds are much higher than that found for the edible part $(0.004 \%)$. Crude fiber is the sum total of all those organic compounds of the plant cell membranes and supporting structures which in chemical analysis of plants foodstuff remain after removal of the crude protein, fat, and nitrogen-free extract; they are commonly used as an index of the value in animal feeding [47].

Some researchers state that sulfur, despite being considered a secondary element, is required in plants in levels similar to phosphorus and that also is a nutrient as necessary as nitrogen $[47,48]$. Boron is an important micronutrient for the formation of cell walls given that it is necessary for pectin synthesis. Likewise, iron is constituent of cytochromes and metalloenzymes; it has roles in photosynthesis, $\mathrm{N}$ symbiotic fixation, $\mathrm{N}$ metabolism, and redox reactions; meanwhile, copper is cofactor of several enzymes with roles in photosynthesis, respiration, carbohydrate, and protein metabolism, among others. Iron is useful for the prevention of anemia and other related diseases and Zinc plays a role in protein synthesis, normal body development, and recovery from illness [47-49]. The results of the bromatological composition suggest that the flour from arazá seeds could be utilized as complementary food.

\section{Physicochemical characterization of the extract and fractions}

The systematic screening of plant species with the purpose of discovering new bioactive compounds is a routine activity in many laboratories which beginning with the extraction (as the term is pharmaceutically used), using selective solvents of increased polarity and characterization of the extracts obtained [50]. The products from the seeds were relatively complex mixtures of metabolites. The amounts of polar metabolites recovered from arazá seed varied depending on the solvent. The extraction yield for REE was high (8.44\%) when compared with $5.54 \%$ and $2.9 \%$ for HR and DF, respectively. Nevertheless, this value could be considered lower than reported for some Myrtaceae fruits; e.g., in Psidium guajava peel was found $29.53 \%$ while the leaves of Psidium guineense revealed a $12.13 \%$ [51]. On the other hand, physicochemical features of REE and fractions (DF and HR) showed little variation among them; for example, it was observed in all a brown coloration and densities $\left(1.35-1.64 \mathrm{~g} / \mathrm{cm}^{3}, 20^{\circ} \mathrm{C}\right)$, brix $(19.8-20.4)$, acidity $(1.07-1.3 \%$ citric acid), and $\mathrm{pH}(5.5-5.6)$ values very similar. The basic parameters influencing the yield and quality of an extract are plant portion and solvent used, location, and extraction procedure, among others.

The evaluation of all the drugs is based on physicochemical and phytochemical approaches which lead to the drug discovery referred as natural product screening. The preliminary qualitative phytochemical screening was carried out on the REE which showed the presence of phenolic compounds, especially tannins. Less abundant were flavonoids, terpenoids, steroids, and saponins. The absence of reducing carbohydrates was noticeable; this is due, at least partially, at the high metabolic rate of the seed at the time of harvest of the fruit in preparation for its germination. The quantitative estimation of phenolic constituents revealed $29.57 \mathrm{~g}$ of GAEs per every $100 \mathrm{~g}$ of REE (g GAE/100 g). This answer not only confirms what was revealed by the qualitative tests but also shows a higher value than the one found by Neri-Numa et al. [15] in arazá pulp ethanolic extracts (18.40 g GAE/100 g) and to what was reported by Garzón et al. [14] for the peel and the pulp (124.3 and $19.3 \mathrm{mg} \mathrm{GAE} / 100 \mathrm{~g}$, respectively). Castro, Restrepo, and Parada [52] determined in the seeds of P. guajava 176, 72 , and $131 \mathrm{mg} \mathrm{GAE} / 100 \mathrm{~g}$ applying Soxhlet method, $\mathrm{CO}_{2}$ supercritical, and $\mathrm{CO}_{2}$ supercritical-ethanol, respectively. At the same time, $\mathrm{HR}$ and DF showed a value of 17.56 and $13.45 \mathrm{~g} \mathrm{GAE} / 100 \mathrm{~g}$, respectively. Matching total phenolic content, the tannic material showed the following order: REE > HR > DF, with values of 29.14, 17.09 and $13.08 \mathrm{~g} \mathrm{GAE} / 100 \mathrm{~g}$, respectively.

The present investigation shows higher values in the contents of these metabolites when compared to above-mentioned results, suggesting that arazá seeds have phenols of diverse chemical nature. Non-tannic phenols (simple phenols, phenylpropanoids, flavonoids, and phenolic acids among others), followed the same pattern (0.42, $0.230 .18 \mathrm{~g}$ $\mathrm{GAE} / 100 \mathrm{~g}$ by REE, HR, and DF, respectively). It could be thought that in the seed of E. stipitata there is the presence of hydrolyzable and nonhydrolyzable tannins (condensed tannins or proanthocyanidins) which, due to their diverse polarity and/or molecular size, showed an uneven distribution in HR and DF [53]. Tannins are found in foliage tissue, flower buds, stem, roots, and seeds; in this latter, are located mainly on a layer between the external tegument and the aleuronic layer; they have been associated to the maintenance of plant dormancy and have allelopathic and bactericide properties [54].

Phenols are the secondary metabolites of relevant importance because of their contribution to human health, besides their widely known and 
recognized action as natural antioxidants [55]. In addition, tannins are used in dying and industries of wine, beer, tea, and cocoa; in pharmacy, they are applied as antidiarrheic [56], antiviral [57], enzymatic inhibitors, and hepatoprotectors [58], angiotensin receptors II AT 1 [59], lipid peroxidation inhibitors [60], and nitric oxide-dependant vasodilators [61].

To establish the chemical fingerprinting of the extract from seed, 22 authentic samples of phenolic compounds (proanthocyanidins, flavonoids, glycoside flavonoids, hydroxycinnamic acid derivatives, and phenolic acid) were used as reference compounds, which exhibited: Isoquercitrin $(0.083 \%)>$ gallic acid $(0.055 \%)>$ phloridzin $(0.026 \%)>$ sinapic acid $(0.023 \%)>$ p-cumaric acid $(0.017 \%)$ as the main constituents; some of which are recognized as antioxidant and oncoprotective activities [62]. Phloridzin reduces glucose absorption, blocking transporters of this molecule into the small intestine, causing a hypoglycemic effect [63]. Despite the chemical attributes found, arazá in Colombia is still a plant of small gardens with low commercialization. The physicochemical characterization of arazá seeds is not been reported earlier.

\section{Antiradical and antioxidant capacities}

Due to the large diversity of antioxidant compounds of REE, DF, and HR, the results of antiradical capacity in this study are given as total antioxidant capacity. The data were uniformly calibrated using the trolox as a reference compound (TEAC). The values of this variable are less influenced by the chemical backbone (main structural elements distinguishing phenolic compound subgroups), than by functional groups attached to the main structure [64]. The comparative assessment showed significant differences between the tested samples as well as between the assays used. There is a great variation in the level of $\mathrm{IC}_{50}$ and $\mathrm{AP}$ values (Table 2).

It can be clearly seen that DF and HR displayed notable antiradical capacity significantly higher than REE $(\mathrm{p}<0.05)$. Likewise, both fractions showed the lowest $\mathrm{IC}_{50}$ and highest $\mathrm{AP}$ values by ABTS assay than the DPPH method $(\mathrm{p}<0.05)$. The different AP percentage obtained from the assay may reflect a relative difference in the ability of antioxidant compounds of DF and HR to quench and reduce aqueous

Table 2: Phenolic content, antiradical and antioxidant activity of arazá seeds

\begin{tabular}{llll}
\hline Assay & \multicolumn{2}{l}{ Sample } & \\
\cline { 2 - 4 } & REE & DF & HR \\
\hline $\begin{array}{l}\text { Antiradical } \\
\text { capacity }\end{array}$ & & & \\
DPPH• & & & \\
IC50 & $3.06 \pm 0.09$ & $2.65 \pm 0.01$ & $2.84 \pm 0.17$ \\
AP & $32.70 \pm 0.50$ & $37.71 \pm 0.80$ & $35.25 \pm 0.81$ \\
TEAC & $659.15 \pm 19.07$ & $759.76 \pm 17.1$ & $710.73 \pm 43.84$ \\
ABTS•+ & & & \\
IC50 & $4.22 \pm 0.02$ & $0.33 \pm 0.01$ & $0.83 \pm 0.04$ \\
AP & $23.69 \pm 0.40$ & $100.01 \pm 0.11$ & $100.09 \pm 0.13$ \\
TEAC & $446.65 \pm 2.82$ & $5491.35 \pm 86.91$ & $2275.40 \pm 110.20$ \\
Antioxidant & & & \\
capacity & & & \\
HI & $247.96 \pm 2.40$ & $200.51 \pm 9.85$ & $222.09 \pm 2.03$ \\
FRAP & $4.05 \pm 0.36$ & NR & NR \\
ORAC & $274.22 \pm 13.76$ & NR & NR \\
•OH & $12.75 \pm 1.98$ & NR & NR \\
\hline
\end{tabular}

REE: Raw ethanolic extract, DF: Dichloromethane fraction,

HR: Hydroalcoholic residue, $\mathrm{IC}_{50}: 50 \%$ inhibitory concentration, $\mathrm{mg} / \mathrm{l}$ )

AP: Antioxidant potential (percent, \%), TEAC: Trolox equivalent antioxidant capacity mmol Trolox/100 g, HI: Hemolysis inhibition ( IC $_{50}$ ), FRAP: Ferric reducing ability of plasma, g AAEC/100 g (Ascorbic acid equivalent antioxidant capacity, $\mu \mathrm{mol} / 100 \mathrm{~g}$ ), ORAC: Oxygen radical absorbance capacity, TEAC, $\cdot \mathrm{OH}$ radical inhibition (DMSOE: Dimethylsulfoxide equivalents, g DMSOE/100 g), NR: Non-reported radicals. TEAC results (Table 2) confirm the $\mathrm{IC}_{50}$ and AP values. ABTS and DPPH methods have the same mechanism reaction that was electron transfer assays. Phenolic antioxidants (ROH) can donate hydrogen atoms to radicals; then, the presence of total phenolics might contribute to the antioxidant capacity of REE, HR, and DF. In this work, the data illustrated higher total phenolic and tannins values in REE, but its antiradical capacity, by DPPH and ABTS tests, was lower, suggesting an indirect correlation between these variables. ANOVA analysis of one way, applied to the analytic determinations related to antiradical capacity, verified variance normality, and homogeneity assumptions $(\mathrm{p}>0.01)$.

Garzón et al. [14] determined in arazá peel 9.0 and $2.0 \mu \mathrm{mol}$ trolox/g FW by DPPHand ABTSassays, respectively; while Brand-Williams, Cuvelier, and Berset [64] determined inedible part 11.0 and $2.6 \mu \mathrm{mol}$ trolox/g FW by two radicals. Based on the above data could be seen that arazá seeds have higher antiradical capacity than peel and edible part.

Weng and Huang [29] state that there are five factors determining in antioxidant capacity of the phenols: (1) Phenolic compound stability after giving hydrogen atoms; (2) number of hydrogen atoms available in every phenolic compound; (3) easiness of interaction between the free radical and the phenolic; (4) how easily the free radicals from phenolic compound can combine with more active free radicals; and (5) the possibility of a new antioxidant can form after the phenolic compound provides hydrogen atoms. Besides, the chemical nature of the radical used as an experimental model and the unit of expression of the results could be also added. The radical scavenging antioxidants play an essential role in the maintenance of health and prevention of diseases; then, evaluate the antiradical capacity of antioxidants is critically important.

In addition to the previous determinations, antioxidant capacity was measured in the raw extract obtained using ORAC and ferric reducing ability of plasma (FRAP) assays, complemented with $\bullet \mathrm{OH}$ radical and hemolysis inhibition tests (Table 2). As a set, the tests made a major approach to bioprospection of the seed in a living organism. The antioxidantcapacities obtained in the present study were high compared to other Myrtaceae fruits. Zapata et al. [31] reported the antioxidant capacity of bitter guava (P. araca), finding: $6.6799 \mathrm{mmol}$ Trolox/100 g, $10.3334 \mathrm{mmol}$ Trolox/100 g, $0.6239 \mathrm{~g} \mathrm{AAE} / 100 \mathrm{~g}$, and $0.6239 \mathrm{~g}$ DMSOE $/ 100 \mathrm{~g}$ by ABTS, FRAP, ORAC, and $\mathrm{OH}^{\bullet}$ radical (terephthalic acid test), respectively. Thaipong et al. [65] reported the antioxidant activity measured in methanol extracts (AOAM) of guava fruits. The average AOAM values were $31.1,25.2,26.1$, and $21.3 \mathrm{mM} \mathrm{TE} / \mathrm{g}$ as determined by the ABTS, DPPH, FRAP, and ORAC assays, respectively. Therefore, comparing the previous results with those obtained in this work it can be affirmed that there are antioxidant compounds in arazá seeds, maybe polyphenols, which may be isolated and analyzed to determine chemical identity. These exhibit biological significant functions such as protection against oxidative stresses and degenerative diseases.

The delicate balance between the advantageous and detrimental effects of free radicals is clearly an important aspect of life. The science of biological redox regulation is a rapidly growing field of research that has an impact on diverse disciplines including physiology, cell biology, and clinical medicine. This seems to be the first report that shows a comparison of four techniques of such activity in arazá seeds.

\section{Anthelmintic activity}

The capacity of REE, DF, and HR to inhibit egg hatching, loss of cuticle, motility, and to induce mortality on GI nematodes and $P$. redivivus mortality induction are given in Table 3. The data revealed that the ethanolic extract showed marked degree anthelmintic activity than DF and HR in all tests on GI nematodes; in addition, it was more effective against free-life organism (P. redivivus) surpassing to DF and HR action, even though all the samples were endowed with the anthelmintic property. 
Table 3: Anthelmintic activity of extract and fractions

\begin{tabular}{|c|c|c|c|c|}
\hline \multirow[t]{2}{*}{ Determinations } & & \multicolumn{3}{|l|}{ Samples } \\
\hline & & REE & DF & HR \\
\hline \multicolumn{5}{|l|}{ GI nematodes } \\
\hline Cuticle loss inhibition & & $11.68 \pm 0.04$ & ND & ND \\
\hline Motility inhibition & & $11.80 \pm 0.21$ & $12.05 \pm 0.23$ & $17.89 \pm 0.52$ \\
\hline Mortality & $\mathrm{LC}_{50}$ & $11.26 \pm 0.23$ & ND & $11.81 \pm 0.06$ \\
\hline \multicolumn{5}{|l|}{$P$. redivivus } \\
\hline Mortality & $\mathrm{LC}_{50}$ & $2.28 \pm 0.31$ & $3.61 \pm 0.04$ & $6.46 \pm 0.11$ \\
\hline
\end{tabular}

REE: Raw ethanolic extract, DF: Dichloromethanic fraction, HR: Hydroalcoholic residue, $\mathrm{IC}_{50}$ : Inhibitory concentration $50 \%\left(\mathrm{mg}_{\mathrm{m}} \mathrm{ml}\right), \mathrm{LC} \mathrm{C}_{50}$ : Lethal concentration

$50 \%$ (mg/ml), ND: Non-detected under test conditions, P. redivivus: Panagrellus redivivus, GI: Gastrointestinal

Statistical analysis applied to these tests showed differences in the activity of the treatments between egg hatching inhibition, GI nematodes motility inhibition, and mortality. The ANOVA confirmed what had been stated before $(\mathrm{p}<0.05)$, was verified variance normality and homogeneity $(\mathrm{p}>0.01)$. Ayala et al. [66] reported a lower $\mathrm{LC}_{50}(0.707 \mathrm{mg} / \mathrm{ml})$ in aqueous extracts of leaves of Eucalyptus globus (Myrtaceae). However, these authors allowed a higher exposition time ( $96 \mathrm{~h})$ to the one used with arazá seeds (24 h).

The anthelmintic activity of REE could be due to the constituents present, mainly the phenols of tannic nature. It is important to mention that condensed tannins have been recognized with the capability to inhibit female fertility and egg hatching in parasitic species T. colubriformis, T. circumcincta, and $H$. contortus $[67,68]$. The presence of such constituents, in synergy with other metabolites (hydrolyzable tannins, flavonoids, saponins, terpenes, among others) found in arazá seeds, would explain partially the higher potentiality of REE in antiparasitic tests.

Complementarily, GI nematodes collected from infected sheep in their $\mathrm{L}_{3}$ stage were identified [35]. The organisms were categorized in three genres according to their main morphological features: Cooperia, as the most abundant (62.50 $\pm 1.29 \%)$; Haemonchus, the second in abundance $(24.00 \pm 2.30 \%)$; and Teladorsagia, the one with the lowest level $(12.50 \pm 1.29 \%)$.

Helminth infections are among the chronic pervasive infection and a foremost degenerative disease distressing a large proportion of the world population [69] and in livestock [70,71]. Evaluation of activities of natural plant products claimed for possessing the anthelmintic property is getting the attention these days. Screening and proper evaluation of the claimed they could offer possible alternatives that may be both sustainable and environmentally acceptable. The results of this study suggested the possible use of E. stipitata seed ethanolic extract in intestinal nematode control.

\section{Cytotoxicity}

With the intention of knowing the possibility that derivative products of E. stipitata seeds can be ingested or applied in some way, this work tested cytotoxicity of the raw extract on mononuclear cells. A mononuclear CV of $96.99 \pm 4.56 \%$ was observed. Rodríguez-Feo et al. [72] suggest that extracts that allow cell feasibility below $80 \%$ can be considered as toxic. Harmlessness of REE, DF, and HR was confirmed on human erythrocytes, the responses were below $3 \%$ which suggests the absence of hemotoxic metabolites in raw extract and fractions obtained from E. stipitata seeds.

\section{CONCLUSIONS}

The study revealed that E. stipitata seeds, commonly known as arazá, collected in the Colombia Andean region, can be used as a food supplement. Biological activity tests carried out lead to consider that many of those would be associated with the joint action of several metabolites distributes irregularly in the samples that were studied, mainly to the phenolic constituents. The presence of this kind of compounds, mostly tannic, enables the seed as a raw material in the elaboration of nutraceutical products with antiradical and/or antioxidant action. In any, its low toxicity confers high probabilities for the product to be ingested or applied in some way. This paper seems to be the first work carried out in Colombia interested in knowing physical, chemical, and biological features of arazá seeds; this information can be useful in food engineering, pharmacological industry (human or veterinarian), botanic, and agronomical. Thus, the use of this residue in arazá fruit chain should give added value to the fruit, reducing the possibilities that its bad provision contributes to environmental contamination.

\section{ACKNOWLEDGMENTS}

The authors acknowledged Natural Products Research Group, GIPRONUT, and LASEREX laboratories of Universidad of Tolima, as well as, Food Science Laboratory of National University, Medellín. The support of Chemistry Department, ETSEA, University of Lleida, Spain, is highly appreciated. We also thank the veterinarian Gisella Olguín for her important contributions. This research was supported financially by the Research and Scientific Development Office of University of Tolima (Project 230220516).

\section{AUTHORS CONTRIBUTIONS}

All the authors made substantial contributions to the conception, design, acquisition, analysis, and interpretation of data.

\section{CONFLICT OF INTEREST}

All authors have none to declare.

\section{REFERENCES}

1. Hernández MS, Martínez O, Fernández-Trujillo J. Behavior of arazá (Eugenia stipitata Mc Vaugh) fruit quality traits during growth, development and ripening. Sci Hortic (Amsterdam) 2007;111:220-7.

2. Quevedo E. Aspectos agronómicos del cultivo de arazá (Eugenia stipitata Mc Vaugh) Frutal promisorio de la amazonia colombiana. Agron Colomb 1995;12:27-65.

3. McVaugh R. Tropical American Myrtaceae: Notes on Generic Concepts and Description of Previously Unrecognized Species. Chicago: Library of the University of Illinois at Urbana-Champaign. Chicago Natural History Museum; 1956. p.104.

4. Hernández M, Barrera J, Carrillo M. Arazá: Origen y Fisiología de Conservación. Bogotá, Colombia: Instituto Amazónico de Investigaciones Científicas - Sinchi; 2006.

5. Evaluaciones Agropecuarias Municipales. Agronet. Bogotá: Evaluaciones Agropecuarias Municipales; 2014.

6. Escobar C, Zuluzaga J, Martinez A. El Cultivo Del Arazá (Eugenia stipitata). CORPOÍCA, editor. Florencia-Caquetá: Graficas Florencia; 1996. p. 1-11.

7. Nascimento SA, Oliveira DF. Manual Técnico, Cultivo y Utilización Arazá (Eugenia stipitata). Amarillo, Fuente: Olga Wacht. A \& C Impresores; 2000. p. 1-92.

8. Millán E, Restrepo P, Narváez C. Efecto del escaldado, de la velocidad de congelación y de descongelación sobre la calidad de la pulpa congelada de arazá (Eugenia stipitata Mc Vaught). Agron Colomb 2007;25:333-8. 
9. Hernández-Gómez MS. Frutas tropicales poco conocidas: Usos y perspectivas. Acta Hortic 2011;906:109-14

10. Narváez-cuenca CE. Extracción y medida de peroxidasa en pulpa de arazá (Eugenia stipitata MC Vaugh). Quim Nova 2008;31:2047-51.

11. Martillo M, Apolo G, Duque A. Fruta amazónica arazá. Rev Caribeña Ciencias Soc 2014;9:1-16.

12. Zhigui E. Obtención de un colorante natura a partir de la pulpa de arazá (Eugenia stipitata); 2015.

13. Cuellar F, Ariza E, Anzola C, Restrepo P. Estudio de la capacidad antioxidante del arazá (Eugenia stipitata Mc Vaugh) durante la maduración. Rev Colomb Química 2013;42:21-8.

14. Garzón G, Narváez-Cuenca C, Kopec RE, Barry AM, Riedl KM, Schwartz SJ. Determination of carotenoids, total phenolic content, and antioxidant activity of arazá (Eugenia stipitata McVaugh), an amazonian fruit. Agric Food Chem 2012;60:4709-17.

15. Neri-Numa IA, Carvalho-Silva LB, Morales JP, Malta LG, Muramoto MT, Ferreira JE, et al. Evaluation of the antioxidant, antiproliferative and antimutagenic potential of araçá-boi fruit (Eugenia stipitata Mc vaugh - myrtaceae) of the Brazilian amazon forest. Food Res 2013;50:70-6.

16. De Souza Schmidt AE, Lajolo FM, Genovese MI. Chemical composition and antioxidant/antidiabetic potential of brazilian native fruits and commercial frozen pulps. J Agric Food Chem 2010;58:4666-74

17. Rogez H, Buxant R, Mignolet E, Souza JN, Silva EM, Larondelle Y. Chemical composition of the pulp of three typical Amazonian fruits: Araza-boi (Eugenia stipitata), bacuri (Platonia insignis) and cupuacu (Theobroma grandiflorum). Eur Food Res Technol 2004;218:380-4.

18. Narváez-cuenca CE, Silva-Bustos KJ, Restrepo-Sánchez LP. Effects of thermal processing combined with sucrose on the vitamin $\mathrm{C}$ content, total phenolic content, antioxidant activity, and sensory characteristics of arazá (Eugenia stipitata McVaugh) purée during frozen storage. Agron Colomb 2015;33:212-9.

19. Vargas AM, Rivera Á, Narváez E. Capacidad antioxidante durante la maduración de arazá (Eugenia stipitata Mc Vaugh). Rev Colomb Química 2005;34:57-65.

20. CORTOLIMA. Agenda Ambiental del Municipio de San Sebastián de Mariquita. Mariquita: Corporación Autónoma Regional del Tolima; 2011.

21. AOAC. Official Methods of Analysis. $16^{\text {th }} \mathrm{ed}$. Washington DC, USA: Association of Official Analytical Chemists; 1995.

22. Nelson N. A photometric adaptation of the somogyi method for the determination of glucose. J Biol Chem 1944;153:375-80.

23. Harborne JB. Phytochemical methods; A guide to modern techniques of plant analysis. J Chem Inform Modeling 1998;33:182-9.

24. Chunduri JR, Shah HR. FTIR phytochemical fingerprinting and antioxidant anlyses of selected indoor non-flowering indoor plants and their industrial importance. Int J Curr Pharm Res 2016;8:37-43.

25. Thangaraj P. In: Rainsford KD, editor. Pharmacological Assays of Plant-Based Natural Products. Coimbatore: Department of Botany, Bharathiar University; 2016. p. 49-53.

26. Delpino-Rius A, Eras J, Vilaró F, Cubero MÁ, Balcells M, CanelaGarayoa R. Characterisation of phenolic compounds in processed fibres from the juice industry. Food Chem 2015;172:575-84

27. Braca A, Sortino C, Politi M, Morelli I, Mendez J. Antioxidant activity of flavonoids from Licania licaniaeflora. J Ethnopharmacol 2002;79:379-81.

28. Marquina V, Araujo L, Ruíz J, Rodríguez-Malaver A, Vit P. Composición química y capacidad antioxidante en fruta, pulpa y mermelada de guayaba (Psidium guajava L.). Arch Latinoam Nutr 2008;58:98-102.

29. Weng XC, Huang Y. Relationship structure-antioxidant activity of hindered phenolic compounds. GrasasAceites 2014;65:e051.

30. Zapata S, Piedrahita AM, Rojano B. Capacidad atrapadora de radicales oxígeno (ORAC) y fenoles totales de frutas y hortalizas de Colombia. Perspect Nutr Hum 2014;16:25-36.

31. Zapata K, Cortes FB, Rojano BA. Polifenoles y actividad antioxidante del fruto de guayaba agria (Psidium araca). Inf Tecnol 2013;24:103-12.

32. Kusmardiyani S, Novita G, Fidrianny I. Antioxidant activities from various extracts of different parts of kelakai (Stenochlaena Palustris) grown in central Kalimantan-Indonesia. Asian J Pharm Clin Res 2016;9:215-9.

33. Duran M, Montero P, Marrugo Y. Extractos metanólicos de corteza de guayaba (Psidium guajava 1.) y mango (Mangifera indica L.): Efecto citotóxico, antihemolítico y en la morfología de membrana de eritrocitos. Rev UDCA Actual Divulg Científica 2013;16:327-34.

34. Pica Y. Ensayo de Toxicidad con el Nemátodo Panagrellus redivivus. México: Ensayos Para Agua Dulce; 1980. p. 139-54.

35. Van Wyk JA, Mayhew E. Morphological identification of parasitic nematode infective larvae of small ruminants and cattle: A practical lab guide. Onderstepoort J Vet Res 2013;80:1-14

36. Paolini V, Bergeaud JP, Grisez C, Prevot F, Dorchies P, Hoste H. Effects of condensed tannins on goats experimentally infected with Haemonchus contortus. Vet Parasitol 2003;113:253-61.

37. de Souza A, Beltrao M. Phenotypic Protocols for Gastrointestinal Nematodes. Methodologies for Diagnosis of Resistance and Detection of Active Substances in Ruminant Parasites; 2009. p. 24-54

38. González-Garduño R, López-Arellano ME, Ojeda-Robertos $\mathrm{N}$, Liébano-Hernández E, Gives PM. Diagnóstico in vitro y en campo de resistencia antihelmíntica en nematodos gastrointestinales de pequeños rumiantes. Arch Med Vet 2014;46:399-405

39. Laboratorio de Genómica viral y Humana Facultad de Medicina Universidad Autonoma de San Luis Potosi. Aislamiento de Células Mononucleares Humanas por Gradiente de Ficoll. México: Laboratorio de Genómica Viral y Humana Facultad de Medicina Universidad Autonoma de San Luis Potosi; 2013. p. 1-4

40. Mosmann T. Rapid colorimetric assay for cellular growth and survival: Application to proliferation and cytotoxicity assays. J Immunol Methods 1983;65:55-63.

41. Patel S, Gheewala N, Suthar A, Shah A. In-vitro cytotoxicity activity of Solanum nigrum extract against hela cell line and vero cell line. Int J Pharm Pharm Sci 2009;1:38-47.

42. Akamine E, Goo T. Respiration and ethylene production in fruits of species and cultivars of Psidium and species of Eugenia. J Am Soc Hortic Sci 1979;98:381-3.

43. Galvis JA, Hernández MS. Comportamiento fisiológico del arazá bajo diferentes temperaturas de almacenamiento (Arazá physiological behavior under different storage temperatures). Colomb Amaz 1993;6:123-34.

44. Pérez RM, Mitchell S, Vargas R. Psidium guajava: A review of its traditional uses, phytochemistry and pharmacology. J Ethnopharmacol 2008; $117: 1-27$

45. Barrantes R, Yaya D, Arias G. Estudio químico bromatológico de diferentes individuos de Eugenia stipitata Mc Vaugh (Arazá). Cienc Invest 2002;1:37-43.

46. Onwuka GI. Food Analysis and Instrumentation: Theory and Practice. Lagos: Naphthali Print; 2005. p. 133-7.

47. Intagri SC. Importancia del Azufre (S) en las Plantas. Nutrición Vegetal. Guanajuato-México: Intagri; 2016. p. 1.

48. Rodríguez C. Efecto del Nitrógeno, Fósforo y Potasio en el Crecimiento y Producción de Plántulas de Tomate (Lycopersicum eculentun Mill) Var Floradade. Nuevo León: Universidad Autónoma de Nuevo León; 1998.

49. Cooman A, Torres C, Fischer G. Determinación de las causas del rajado del fruto de uchuva (Physalis peruviana L.) bajo cubierta. II. Efecto de la oferta de calcio, boro y cobre. Agron Colomb 2005;23:74-82.

50. Foye WO, Lemke DA, Williams DA. Foye's Principles of Medicinal Chemistry. $6^{\text {th }}$ ed. Philadelphiap, PA: Lippincott Williams and Wilkins; 2008. p. 44-5

51. Neira A, Ramírez M. Actividad antibacteriana de extractos dos especies de guayaba contra Streptococus muntans y Escherichia coli. Rev Actual Biol 2005;27:27-30.

52. Castro H, Restrepo P, Parada F. Semillas de guayaba: Residuo o subproducto? In: Bogotá S, editor. Desarrollo De Productos Funcionales Promisorios A Partir De La Guayaba (Psidium guajava L) Para El Fortalecimiento De La Cadena Productiva. Bogotá: Universidad Nacional de Colombia; 2010. p. 189-98.

53. Porras A, López-Malo A. Importance of phenolic groups in foods. SelectTop Food Eng 2009;3:121-34.

54. Ashok P, Upadhyaya K. Tannins are astringent. J Pharmacogn Phytochem 2012;1:45-50.

55. Jaramillo M, Salinas V, Ochoa G. Los antioxidantes de los alimentos y su relación con las enfermedades crónicas. El Chocolate y su Contenido de Antioxidantes. Medellín: Sociedad Colombiana de Cardiologia; 2004. p. 43.

56. Machado TB, Pinto AV, Pinto MC, Leal IC, Silva MG, Amaral AC, et al. In vitro activity of Brazilian medicinal plants, naturally occurring naphthoquinones and their analogues, against methicillin-resistant Staphylococcus aureus. Int J Antimicrob Agents 2003;21:279-84.

57. Ahn MJ, Yoon KD, Min SY, Lee JS, Kim JH, Kim TG, et al. Inhibition of HIV-1 reverse transcriptase and protease by phlorotannins from the brown alga Ecklonia cava. Biol Pharm Bull 2004;27:544-7.

58. Kim YC, An RB, Yoon NY, Nam TJ, Choi JS. Hepatoprotective constituents of the edible brown alga Ecklonia stolonifera on tacrineinduced cytotoxicity in Hep G2 cells. Arch Pharm Res 2005;28:1376-80.

59. Caballero-George C, Vanderheyden PM, De Bruyne T, Shahat AA, Van Den Heuvel H, Solis PN, et al. In vitro inhibition of $[3 \mathrm{H}]$-angiotensin II binding on the human AT1 receptor by proanthocyanidins from 
Guazuma ulmifolia bark. Planta Med 2002;68:1066-71.

60. Okuda T. Systematics and health effects of chemically distinct tannins in medicinal plants. Phytochemistry 2005;66:2012-31.

61. Fumagalli F, Rossoni M, Iriti M, Di Gennaro A, Faoro F, Borroni E, et al. From field to health: A simple way to increase the nutraceutical content of grape as shown by NO-dependent vascular relaxation. J Agric Food Chem 2006;54:5344-9.

62. Mura F. Estudio de la Actividad Antioxidante y Potencial Capacidad Citotóxica en Células Leucémicas de la línea HL-60 de Nuevos Compuestos Derivados de Ácido Hidroxicinámico. Portugal: Universidad de Chile; 2016.

63. Houssay BA. El descubrimiento de la diabetes pancreática. Rev Argentina Endocrinol Metab 2015;52:2-7.

64. Brand-Williams W, Cuvelier ME, Berset C. Use of a free radical method to evaluate antioxidant activity. LWT Food Sci Technol 1995;28:25-30.

65. Thaipong K, Boonprakob U, Crosby K, Cisneros-Zevallos L, Byrne DH. Comparison of ABTS, DPPH, FRAP, and ORAC assays for estimating antioxidant activity from guava fruit extracts. J Food Compos Anal 2006;19:669-75.
66. Ayala H, Iannacone J, Alvariño L. Toxicity of five botanical aqueous extracts on Panagrellus redivivus. Neotrop Helminthol 2017;11:139-55.

67. Githiori JB, Athanasiadou S, Thamsborg SM. Use of plants in novel approaches for control of gastrointestinal helminths in livestock with emphasis on small ruminants. Vet Parasitol 2006;139:308-20.

68. Bernal A, Camargo Á. Efecto in vitro de los taninos condensados de las plantas Leucaena leucocephala, Calliandra calothyrsus y Flemingia macrophylla sobre Huevos y Larvas (L3) de Nemátodos Gastrointestinales de Ovinos. Bogotá: Universidad de La Salle; 2016.

69. Partap S, Kumar S, Kumar A, Sharma NK, Jha KK. In-vitro anthelmintic activity of Luffa cylindrica leaves in indian adult earthworm. J Pharmacogn Phytochem 2012;1:27-30.

70. Coop RL, Kyriazakis I. Nutrition-parasite interaction. Vet Parasitol 1999;84:187-204.

71. Koski KG, Scott ME. Gastrointestinal nematodes, trace elements, and immunity. J Trace Elem Exp Med 2003;16:237-51.

72. Rodríguez-Feo JA, Gómez J, Núñez A, Rico L, Fortes J, De AR, et al. Doxazosina y guanilato ciclasa soluble en un modelo de ratas hipertensas. Rev Española Cardiol 2001;54:880-6. 